\title{
Lectotype designations for Ptychoderini species (Coleoptera, Anthribidae, Anthribinae) of the Muséum National d'Histoire Naturelle
}

\author{
Jose Ricardo M. Mermudes ${ }^{1}$
}

${ }^{1}$ Laboratório de Entomologia, Departamento de Zoologia, Universidade Federal do Rio de Janeiro. Caixa Postal 68044, $21941-971$ Rio de Janeiro-RJ, Brazil.jrmermudes@gmail.com

\begin{abstract}
Lectotype designations for Ptychoderini species (Coleoptera, Anthribidae, Anthribinae) of the Muséum National d'Histoire Naturelle. Based on a study of the type material housed in the Muséum National d'Histoire Naturelle Paris, lectotypes are designated for the following species: 1) described by Jekel in 1855 - Ptychoderes columbianus, P. callosus, P. mixtus, P. antiquus, Hypselotropis batesi, Ectatotropis conicollis, and Tropipygus speciosus; 2) described by Thomson in 1858 - Phloeotragus sparsutus. The following species have the type specimens illustrated: Ptychoderes mixtus, lectotype female; P. tricostifrons, holotype male; Hypselotropis speciosa, lectotype male; Phloeotragus sparsutus, lectotype male and paralectotype female.
\end{abstract}

KEYWORDS. Afrotropical; Hypselotropis; neotropical; Phloeotragus; Ptychoderes; type material.

\begin{abstract}
RESUMO. Designação de lectótipos de espécies em Ptychoderini (Coleoptera, Anthribidae, Anthribinae) do Muséum National d'Histoire Naturelle. Com base no estudo do material-tipo depositado no Muséum National d'Histoire Naturelle, Paris, são designados lectótipos para as seguintes espécies: 1) descritas por Jekel in 1855 -Ptychoderes columbianus, P. callosus, P. mixtus, P. antiquus, Hypselotropis batesi, Ectatotropis conicollis, e Tropipygus speciosus; 2) descritas por Thomson in 1858 - Phloeotragus sparsutus. As seguintes espécies têm o material-tipo ilustrado: Ptychoderes mixtus, lectótipo fêmea; P. tricostifrons, holótipo macho; Hypselotropis speciosa, lectótipo macho; Phloeotragus sparsutus, lectótipo macho e paralectótipo fêmea.
\end{abstract}

PALAVRAS-CHAVE. Afrotropical; Hypselotropis; Neotropical; Phloeotragus; Ptychoderes; material-tipo.

The collections of Anthribidae in the Muséum National d'Histoire Naturelle (MNHN), in Paris, France, are among the most extensive holdings in Europe. The number of primary types is enormous, and many of them need to be revised. I studied the material of Anthribidae in MNHN, based on my own recent revisions, one of Ptychoderes Schoenherr, 1823 (Mermudes \& Napp 2006), and another of Hypselotropis Jekel, 1855 (Mermudes 2005); and on new studies with the entire tribe Ptychoderini Jekel, 1855.

These studies, together with other revisions of primary types, mainly from the Natural History Museum in London (BMNH), allowed the recognition of several available types, as done by authors who have previously published on antribids, including Barry D. Valentine and D. Solange Napp.

The present study is the result of the examination of the types of the species described by Henry Jekel in the genera Ptychoderes and Hypselotropis (= Tribotropis Jekel, $1855 ;=$ Ectatotropis; $=$ Tropipygus); the species described by Thomson (1858) in the genus Phloeotragus Schoenherr, 1823; and the species described by Fåhraeus (1839) in the genus Ptychoderes. The lectotypes are selected for eight taxa (Ptychoderes columbianus Jekel, P. callosus Jekel, $P$. mixtus Jekel, P. antiquus Jekel, Hypselotropis batesi Jekel, Ectatotropis conicollis Jekel, Tropipygus speciosus Jekel and Phloeotragus sparsutus Thomson). On the other hand, only one case was based on a single specimen [Ptychoderes tricostifrons (Fåhraeus)], which I recognize as the holotype according to International Code of Zoological Nomenclature (ICZN 1999: article 73).
Jekel (1855), in the original descriptions of species, mentioned a series of specimens without selecting a holotype. The fourth edition of the ICZN requests an express statement of the taxonomic purpose in lectotype designation (ICZN 1999: article 74.7.3). Therefore, the following lectotypes designation is necessary to fix clearly the status of the taxon name. Even some of the names are currently in synonymy [as P. columbianus Jekel and P. tricostifrons (Fåhraeus)] according to Mermudes \& Napp (2006) and the designation also are necessary because ICNZ notice that name are unavailable (ICZN 1999).

The material of the species described by Jekel (1855) is currently included in the ex-collections Fairmaire housed in MNHN. All designations included a red label, on which was printed "Lectotype" or "Paralectotype", and hand-written "the species-name" and "Mermudes det. 07".

In light of recent revisions (Mermudes 2005; Mermudes \& Napp 2006) the references for each taxon are limited to the original description and these revisions that also includes the last catalogue (Rheinheimer 2004).

Tribe Ptychoderini Jekel, 1855

Ptychoderidae Jekel, 1855: 70 [Ptychoderes Schoenherr, 1823 - type genus].

Ptychoderini; Alonso-Zarazaga \& Lyal, 1999: 33 (cat.).

\section{Ptychoderes Schoenherr, 1823}

Ptychoderes Schoenherr, 1823: 1135; Mermudes \& Napp, 2006: 14 (revision). 


\section{Ptychoderes nebulosus (Olivier, 1795)}

Macrocephalus nebulosus Olivier, 1795 ( $\mathrm{n}^{\circ}$ 80): 5, t. 1, fig. 3 a-c.

Ptychoderes nebulosus; Schoenherr, 1823: col. 1135; Jekel, 1855: 48; Rheinheimer, 2004: 10 (cat.); Mermudes \& Napp, 2006 (revision).

Ptychoderes tricostifrons Fåhraeus in Schoenherr, 1839: 158; Jekel, 1855: 53; Jordan, 1906: 303, t. 10, Figs. 1, 1a; Mermudes \& Napp, 2006 ( in synonymy).

Ptychoderes nebulosus s. tricostifrons [sic]; Rheinheimer, 2004: 10 (cat.).

Ptychoderes columbianus Jekel, 1855: 50; Mermudes \& Napp, 2006 ( in synonymy).

Ptychoderes nebulosus s. columbianus [sic]; Rheinheimer, 2004:10 (cat.).

Ptychoderes columbianus Jekel, 1855 and P. tricostifrons Fåhraeus, 1839 were synonymized under $P$. nebulosus (Olivier, 1795) by Mermudes \& Napp (2006). Here, lectotypes are designated for the former two species.

With reference to $P$. columbianus, Jekel (1855) did not mention the number of specimens he studied. The examples were recorded from Colombia (Bogota and Cartagena) and Brazil (Amazonas and Pará). Three syntypes (a male and two females) were found at MNHN. The specimens have a single common label fixed at the bottom of the box, written: "Columbianus/ Jek. Ins. Saund./ Columb. LECTOTYPE male (here designated): with a red label printed: "Mermudes det./Lectotype" and, on the reverse, written: "Ptychoderes columbianus male". PARALECTOTYPES: 1 female, "Columb" (green square); 1 female, "v. Amazonae/Jekel" (white square), another "Hord/Hoffaman" (white square).

Respecting P. tricostifrons, Mermudes \& Napp (2006) mentioned the Naturhistoriska Riksmuseet, Stockholm (NHRS) as the depository of the holotype, which was not examined by the authors in their revision. Later on, Dr. Bert Viklund (personal communication) stated:

" ...The other type is not here and was most likely sent back to Chevrolat after the description, so the type material of $P$. tricostifrons is indeed to be searched for in the Paris museum. It should be included in the collection of Maurice Sedillot (1849-1933), a collection that the Paris museum achieved in 1935."

In fact, the holotype of P. tricostifrons (Figs. 2-4) was found at MNHN. It is a small male of P. nebulosus (Olivier, 1795) (see Mermudes \& Napp 2006 for male dimorphism), and bears the following labels (Figs. 3, 4): 1) orange square; 2) "5" hand-written (white square); 3) "Mexico 608/ Pheo[n] ola[t.]"; on the reverse "B.D.V.' 70". The holotype was studied by Jekel (1855: 54) that mentioned it in "Chevrolat's cabinet". The exam of the holotype confirms the synonymy of $P$. tricostifrons under $P$. nebulosus as proposed by Mermudes \& Napp (2006).

\section{Ptychoderes callosus Jekel, 1855}

Ptychoderes callosus Jekel, 1855: 54; Mermudes \& Napp, 2006: 51 (revision).

Four syntypes (one male and 3 females) set on a single label fixed at the bottom of the box, written: "Callosus/ Jek. Ins. Saunders./ Cayenne".

LECTOTYPE male (here designated), labelled: hand- written label on the box written: "Cayenne Dupon (green rectangular)"; red rectangular label printed "Lectotype/ Mermudes det. 07", and, on the reverse, hand-written "Ptychoderes callosus J., male". PARALECTOTYPES, 3 females: 1 female "Cayenne Bar" (white rectangle); 1 female "Cay. Bar." (white square); 1 female "Cayenne" (white rectangle).

\section{Ptychoderes mixtus Jekel, 1855}

Ptychoderes mixtus Jekel, 1855: 57; Mermudes \& Napp, 2006: 44 (revision).

Jekel (1855) studied specimens from French Guiana (Cayenne) and Brazil ("Rio Negro), not mentioning the number of examples. A single female was located at MNHN.

LECTOTYPE female (Fig. 1, here designated): with labels: "Brésil/Chv. ct." (white rectangle); "varicornis/Chev./ male coll.Chev." The syntypes studied by Mermudes \& Napp (2006), one male and two females from the Chevrolat Collection, were not located.

\section{Ptychoderes antiquus Jekel, 1855}

Ptychoderes antiquus Jekel, 1855: 59; Mermudes \& Napp, 2006: 62 (revision).

Two female syntypes lacking individual labels, set on a single common label fixed at the bottom of the box, written: "Antiquus Kl./ Jek. Ins. Saund. Bahia".

LECTOTYPE female (here designated): with red printed label reading "Lectotype", and hand-written on the reverse: "Ptychoderes antiquus/ Jekel, female. Mermudes det. 07". PARALECTOTYPE: 1 female with red printed label reading "Paralectotype", hand-written on the reverse: "female/ Ptychoderes antiquus/ Jek. Mermudes det. 07".

For two species, Ptychoderes depressus Jekel and $P$. obsoletus Jekel, the type material was not located. However, hand-written labels on the bottom of the box read, (on the first) near the former : "Depressus /Jekel, Ins. Saund./ Brasilia" and (on the second) near the latter: "Obsoletus/ Jek. Ins. Saund./ Brasil". The type material is probably housed in the BMNH, according to Pitkin (2003). Mermudes \& Napp (2006) noted that Jekel (1855) did not mention the number of specimens studied.

\section{Hypselotropis Jekel, 1855}

Hypselotropis Jekel, 1855: 65; Mermudes, 2005: 476 (revision).

\section{Hypselotropis batesi Jekel}

Hypselotropis batesi Jekel, 1855: 66; Mermudes, 2005: 493 (revision).

In the recent paper, Mermudes (2005) erroneously reported that Jekel (1855:66) studied one specimen, but in the next page, Jekel referred other specimens of $H$. batesi herein designated. Four specimens near the label on the 

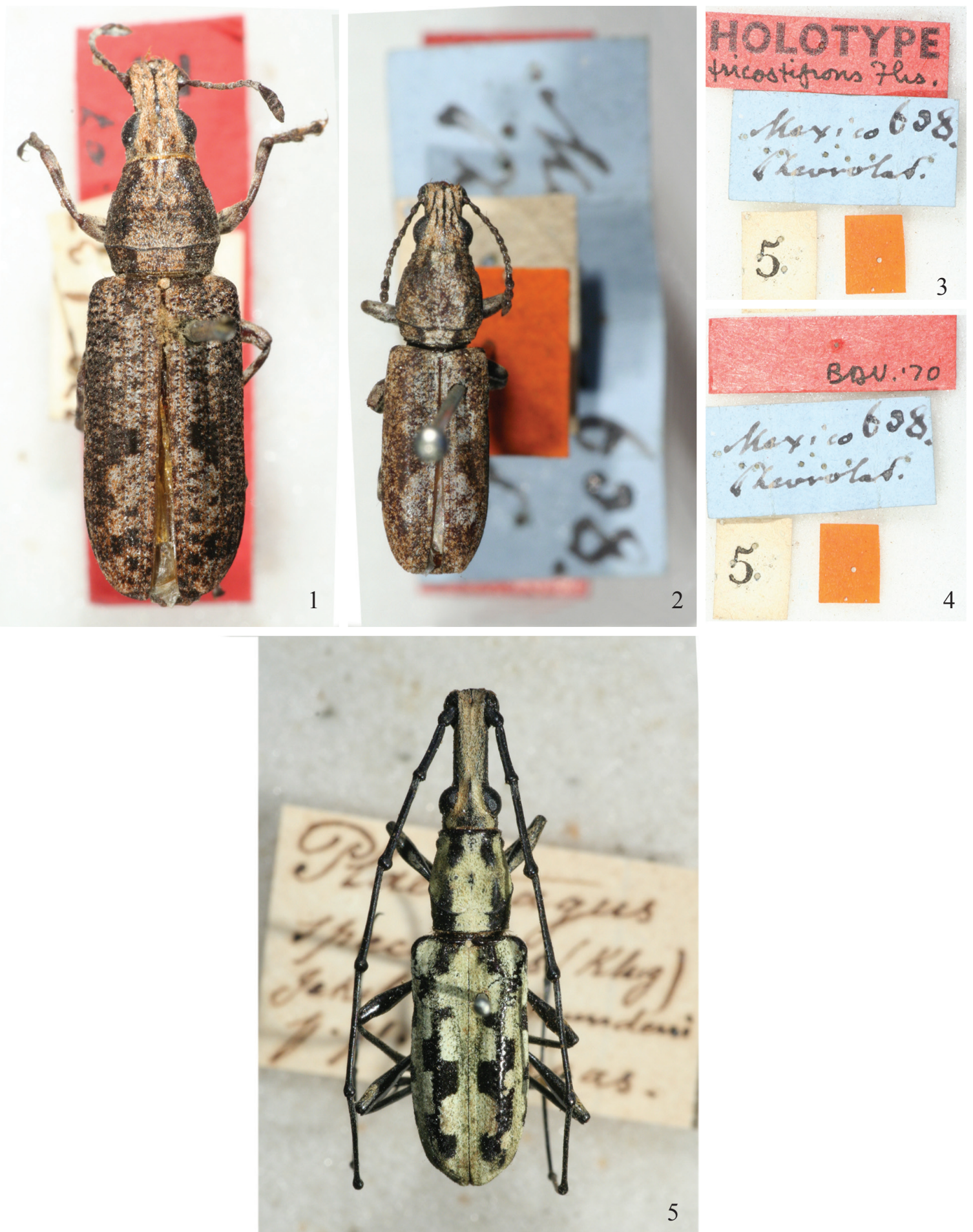

Figs. 1-5. 1, Ptychoderes mixtus, Lectotype female. 2-4: 2, Ptychoderes tricostifrons, Holotype male; 3 and 4, labels. 5, Hypselotropis speciosa, Lectotype male.

bottom of the box: "Hypselotropis/ Batesii Jek./ Amaz. / Ins. Saund." LECTOTYPE: male (here designated):, with printed red label reading "Lectotype", on the reverse hand-written "Hypselotropis batesi, Jekel. male, Mermudes det. 07"; another white rectangle reading: "Amazon.". PARALECTOTYPES: 1 male with the label: "Amazones. Dup." (white rectangle); 1 female with the label "Amaz. Stand (white square); 1 female without data.

\section{Hypselotropis conicollis (Jekel, 1855)}

Tribotropis (Ectatotropis) conicollis Jekel, 1855: 73.

Hypselotropis conicollis; Mermudes, 2005: 486 (revision).

Two syntypes near the label on the bottom of the box, written:"EctatotropisJek./conicollisJek./Ins.Saund./Cayen.”. LECTOTYPE male (here designated): missing antennae, with 

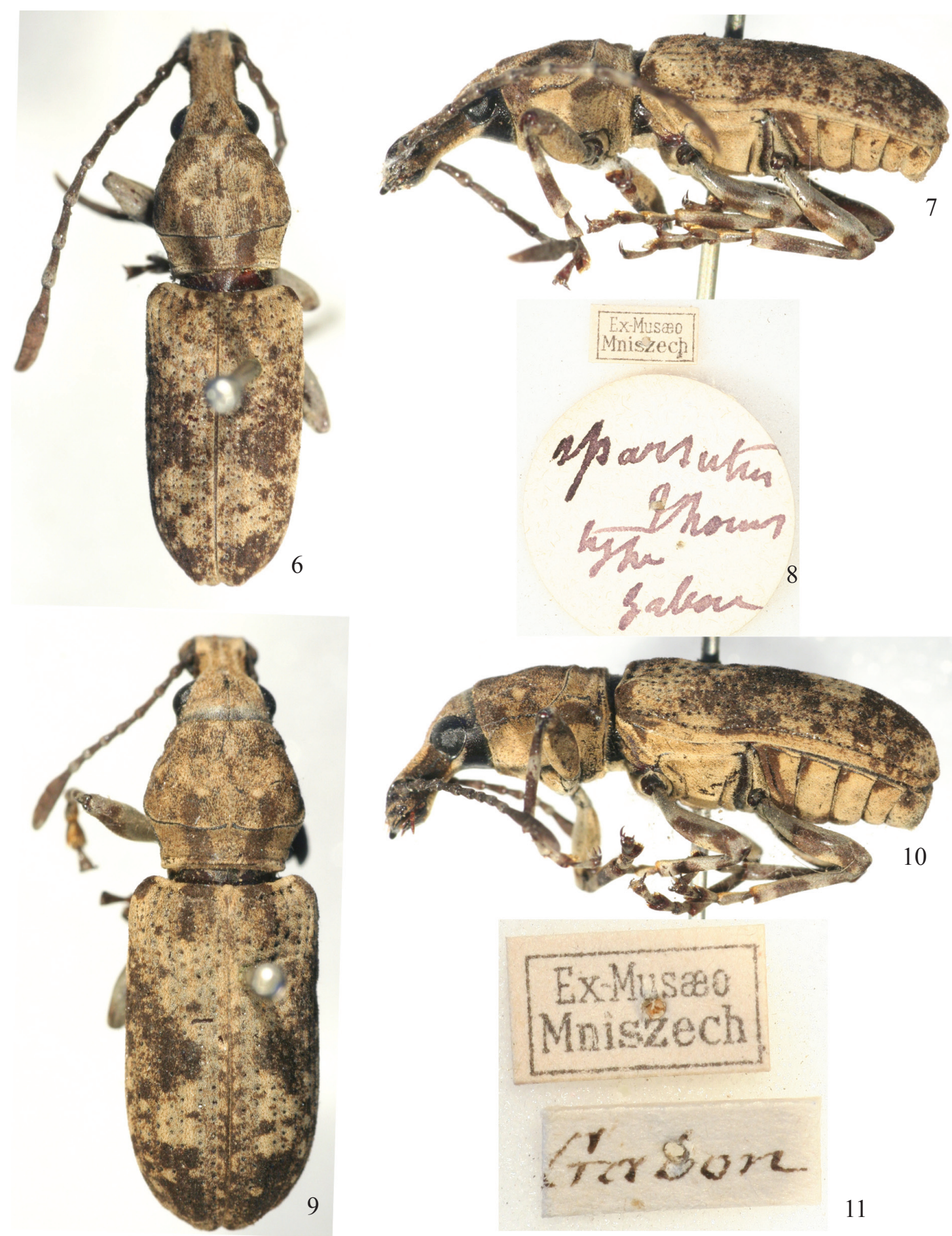

11

Figs. 6-11. Phloeotragus sparsutus, 6, Lectotype male, dorsal habitus, 7, lateral habitus, 8, labels. 92, Paralectotype female, dorsal habitus, 10, lateral habitus, 11, labels.

red printed label reading "Lectotype" and another, white square, reading "Cay./ Bar". PARALECTOTYPE: 1 female with two labels: 1) "Cayen" (white square); 2) "conicollis Jek. n. sp.” (white square).

\section{Hypselotropis speciosa (Jekel, 1855)}

Tribotropis (Tropipygus) speciosus Jekel, 1855: 77. Hypselotropis speciosa; Mermudes, 2005: 503 (revision).
Mermudes (2005) reported that the type-material of this species was not examined because it was not located at MNHN at that time. Jekel (1855) based the species on examples recorded from Colombia and Venezuela.

LECTOTYPE male (Fig. 5) (here designated): with red printed label reading "Lectotype", and hand-written "Mermudes det. 07". PARALECTOTYPES, 5 males and 3 females: only 1 male with blue rectangular label, hand- 
written: "Phloeotragus/ speciosus/ Klug / Caracas". Seven additional paralectotypes in the ex-collections A. Sallé (MNHN): 1 male, with square white label "Phloeotragus/ speciosus (Klug)/ Jekel Ins. Saundersi/ Caracas"; 2 males and 2 females without data; 1 male with square green label "Phloeotragus/ tesselatus Chevr/ Caracas".

\section{Phloeotragus Schoenherr, 1823}

Phloeotragus Schoenherr, 1823: 1135

\section{Phloeotragus sparsutus Thomson, 1858}

Phloeotragus sparsutus Thomson, 1858: 110; Jordan, 1895: 130; Rheinheimer, 2004: 11.

LECTOTYPE male (Figs. 6, 7) (here designated): with labels (Fig. 8): 1) "sparsutus / Thoms/ type / Gabon" (large round white label, hand-written); 2) "Ex-Musaeo Mniszech" (white rectangle, printed); 3) "Lectotype/ Mermudes det. 2007", on the reverse hand-written "Phloeotragus sparsutus Thomson". PARALECTOTYPE female (Figs. 9, 10) with labels (Fig. 11): 1) "Gabon" (white rectangle); 2) "ExMusaeo Mniszech" (white rectangle); 3) "Paralectotype" (red rectangle).

Acknowledgements. I am grateful to Hélène Perrin, curator of the collections of Curculionoidea at the MNHN, for allowing me to study the collections of Anthribidae, and Bert Viklund (Swedish Museum of Natural History) for informations on Fåhraeus' holotype. I thank Marcela L. Monné (Museu Nacional, Universidade Federal do Rio de Janeiro, Brazil) for encouraging me to carry out this study. I also thank Janet W. Reid for reviewing the English text and two anonymous reviewers for their valuable comments.

\section{REFERENCES}

International Commission of Zoological Nomenclature [ICZN].1999. International code of zoological nomenclature [the Code]. Fourth edition. The International Trust for Zoological Nomenclature, c/o Natural History Museum, London. xxix +306 p. [online version at http://www. iczn.org/iczn/index.jsp].

Fåhraeus, O. I. 1839. In: Schoenherr, C. J. Genera et species Curculionidum cum synonymia hujus familiae: species novae aut hactenus minus cognitae, descriptionibus a Dom. Leonardo Gyllenhal, C. H. Boheman, et entomologis aliis illustratae. Lipsiae, Fleischer, Roret, Paris, 5: 1-456.

Jekel, H. 1855. Insecta Saundersiana or characters of undescribed insects in the collection of William Wilson Saunders (Coleoptera, Curculionidae). Part 1, 153 p.

Mermudes, J. R. M. 2005. Revisão sistemática, análise cladística e biogeografia dos gêneros Tribotropis e Hypselotropis (Coleoptera, Anthribidae, Anthribinae, Ptychoderini). Revista Brasileira de Entomologia 49: 465-511.

Mermudes, J. R. M. \& D. S. Napp. 2006. Revision and cladistic analysis of the genus Ptychoderes Schoenherr, 1823 (Coleoptera, Anthribidae, Anthribinae, Ptychoderini) Zootaxa 1182: 1-130.

Pitkin, B. (Ed.). 2003. The Coleoptera Collection and Card Index. World Wide Web electronic publication. Available from http://www.nhm.ac.uk/ entomology/collections/beetles/ [accessed 24 September 2004].

Rheinheimer, J. 2004. Illustrater Katalog und Bibliographie der Anthribidae der Welt (Insecta: Coleoptera). Mitteilungen des Entomologischen Vereins Stuttgart 39: 3-242.

Schoenherr, C. J. 1839. Genera et species Curculionidum cum synonymia hujus familiae: species novae aut hactenus minus cognitae, descriptionibus a Dom. Leonardo Gyllenhal, C. H. Boheman, et entomologis aliis illustratae. Lipsiae, Fleischer, Roret, Paris, 5:1-456.

Thomson, J. 1858. Archives entomologiques ou Recueil contenant des illustrations d'insectes nouveaux our rares. Tome 2, Paris, $469 \mathrm{p}$. 